\title{
Evaluation of certain Penicillium frequentans isolates against Cercospora leaf spot disease of sugar beet
}

\author{
Mansour M. El-Fawy', Rafeek M. I. El-Sharkawy ${ }^{1}$ and Kamal A. M. Abo-Elyousr ${ }^{2^{*}}$ (D)
}

\begin{abstract}
The impact of six local isolates of Penicillium frequentans recovered from healthy sugar beet (Beta vulgaris L.) leaves was evaluated against Cercospora beticola, the causal pathogen of Cercospora sugar beet leaf spot under laboratory and field conditions. In in vitro studies, all the six isolates were able to inhibit the mycelial growth of C. beticola with variation in their antagonistic capability. P. frequentans isolates produce pectinase and cellulase at different degrees. There was a correlation between enzyme activity and the antagonistic ability for each isolate. The high antagonistic ability isolates had the most enzyme activity. In field studies, some adhesives such as agar, starch flour, white glue, gum, and commercial adhesive (Triton Mok) were added to conidia spore suspensions of $P$. frequentans at $1 \%$ to improve conidial adhesion to sugar beet plant surface. Data also showed that all adhesives increased $(P=0.05)$ the efficiency of the spore suspension of $P$. frequentans to control the disease. The starch flour at $1 \%$ gave a significant reduction in disease severity from 43.23 to $10.42 \%$ pre-infection and from 43.23 to $10.52 \%$ post-infection. The application of $P$. frequentans led to improved root yield and the sugar percent of sugar beet crop in two tested seasons.
\end{abstract}

Keywords: Biological control, Penicillium frequentans, Isolates, Cercospora leaf spot disease, Sugar beet, Antagonist, Sugar content, Root yield

\section{Background}

Cercospora leaf spot caused by Cercospora beticola is the most destructive leaf disease of sugar beet in all production areas (Piszczek et al. 2017). It causes reduction in root weight and extractable sucrose yields increases impurity concentrations resulting in higher processing losses and can lead to reductions in gross sugar yield of up to $42 \%$ (Shane and Teng 1992).

The genus of Penicillium has major importance in the natural environment as well as food and drug production (Ropars et al. 2014). Carlton et al. (1976) reported that Penicillium species have been also suppressing the bacterial growth in a number of studies. A much diversified array of active secondary metabolites, including potent mycotoxins (Frisvad and Samson 2004) and antibacterial (Rancic et al. 2006; Lucas et al. 2007) and antifungal substances (Nicoletti et al. 2007). These secondary metabolites

\footnotetext{
* Correspondence: kaaboelyousr@agr.au.edu.eg

${ }^{2}$ Plant Pathology Department, Faculty of Agriculture, Assiut University, Assiut

71526, Egypt

Full list of author information is available at the end of the article
}

of Penicillium species have been identified as well as proved their biological activities (Silva et al. 2004). Antibiotic-based products are one of the biochemical mechanisms regulating antagonism between soil fungi that may also influence fungi stasis and the suppressive properties of certain soils toward plant pathogens (Frisvad and Samson 2004).

Penicillium frequentans Westling is reported as a biological control agent (De Cal et al. 1990). It has shown a good potential for development as a commercial biocontrol product against the brown rot of peach fruit (Guijarro et al. 2006, 2007). It produced high levels of extracellular pectinases after $24 \mathrm{~h}$ of incubation in submerged culture (Kawano et al. 1999). Antibiotics produced by $P$. frequentans are active against Monilinia laxa spore germination and germ-tube growth and may be related to the control of the pathogen (De Cal et al. 1988). Some preparations of $P$. frequentans gave a significant reduction in severity of the disease (from 38 to $80 \%$ ) comparable to that given by the fungicide Captan (De Cal et al. 1990). 
Severe environmental conditions may drastically limit the establishment and survival of a biocontrol agent on a host target site (Schisler et al. 2004; Bonaterra et al. 2007). Therefore, formulation of biocontrol agents could be effective to protect them when applied on aerial plant parts. Adhesives improve spore adhesion to the target leaf and prevent wash-off by rain (Schisler et al. 2004).

The present work was planned to study the efficiency of $P$. frequentans isolates in controlling Cercospora leaf spot disease of sugar beet and evaluate the effect of different adhesives to improve conidial adhesion of $P$. frequentans to sugar beet plant surface.

\section{Materials and methods}

\section{Isolation and identification of fungal isolates}

Six isolates of $P$. frequentans recovered from healthy sugar beet leaves. The fungal isolates were identified according to their morphological and microscopic characteristics of conidia spores (Pitt 1979) and confirmed by Assiut University Mycological Center (AUMC), Assiut, Egypt. The pathogenicity of $P$. frequentans isolates was tested on sugar beet (Beta vulgaris subsp. vulgaris L.), table beet (Beta vulgaris L.), turnip (Brassica rapa L.), spinach (Spinacia oleracea L.), Swiss chard (Beta vulgaris var. cicla L.), and radish (Raphanus sativas L.) plants under greenhouse conditions to confirm that it is not pathogenic to plants. The spore suspension of $P$. frequentans isolates was prepared by growing it on PDA medium. The growth isolates were collected and blended using a warring blender. The concentration of spore suspension was adjusted to $1 \times 10^{5}$ per milliliter of water using a hemacytometer. The tested plants were sprayed with spore suspensions until runoff and covered with clear plastic bags to maintain high humidity. Covering bags were loosened after $24 \mathrm{~h}$ and removed after $48 \mathrm{~h}$, and then inoculated plants were kept under natural humidity as mentioned by El-Fawy and Abo-Elyousr (2016). Control plants were sprayed with distilled water and three pots for each treatment as replicates. Regular observations were made to record appearance of symptoms or not.

A pathogenic isolate of $C$. beticola previously recovered from sugar beet plants, showing typical symptoms of Cercospora leaf spot disease, was used in this study (El-Fawy 2016).

\section{In vitro, the antagonistic effect of $P$. frequentans on C. beticola}

The antagonistic effect of six $P$. frequentans isolates against $C$. beticola was investigated in Petri dishes containing potato agar dextrose (PDA) medium. Each plate was inoculated on both sides with 6-mm discs from 7-day-old cultures of individual antagonistic fungal isolates. Also, one disc from 7-day-old cultures of
C. beticola was placed in the center of the same plate. Four plates were used for each treatment as replicates. Inoculated plates with the pathogen only were used as a control. The inoculated plates were incubated at $25{ }^{\circ} \mathrm{C}$. The antagonistic abilities of $P$. frequentans isolates were recorded when the growth of $C$. beticola isolates completely covered surface of control plates. The percentage of growth inhibition was calculated according to the equation of Abo-Elyousr et al (2014):

$$
R=(C-B / C) \times 100
$$

where $R=\%$ of growth inhibition, $C=$ growth in the control, and $B=$ growth in the treatment.

\section{Effect of culture filtrate of $P$. frequentans on mycelial growth of $C$. beticola}

The isolates of $P$. frequentans showed high antagonistic abilities (Nos. 2 and 4) were grown in a 250-ml flask containing $100 \mathrm{ml}$ of malt extract (ME) broth and incubated for 15 days at $25{ }^{\circ} \mathrm{C}$. At the end of the incubation period, $P$. frequentans liquid cultures were filtered first through filter paper to remove the mycelia. Then, the filtrates were centrifuged for $60 \mathrm{~min}$ at $3000 \mathrm{rpm}$ to separate the fungal growth (Mohamed et al. 2008). Culture filtrate was sterilized using Seitz filter. The sterilized filtrates were added to PDA medium at concentrations of $5,10,20,30$, and $40 \% v: v$ (filtrate: medium) and mixed thoroughly before solidification. Petri dishes were inoculated in the center with 6-mm discs of C. beticola and incubated at $25{ }^{\circ} \mathrm{C}$. Petri dishes without culture filtrate were used as a control. Four plates were used for each treatment as replicates. Data were recorded as a diameter of linear growth when the control plates were completely covered by the fungal mycelium. Different concentrations from culture filtrates were tried until complete inhibition of $C$. beticola growth was achieved. The percentage of growth inhibition was calculated as previously mentioned.

\section{Pectinase and cellulase activity}

The ability of the six isolates of $P$. frequentans to produce pectinase and cellulase enzymes was determined using enzyme activity-plate tests. Czapek Dox Agar (CZA) medium as described by Panda et al. (2012) containing $1 \%$ pectin and carboxymethyl cellulose was used for evaluating pectinolytic and cellulolytic activities, respectively. CZA plates were inoculated with 6-mm discs of $P$. frequentans isolates. Four plates for each isolate were used as replicates. Inoculated plates were incubated at $25{ }^{\circ} \mathrm{C}$ for one week. Pectinolytic and cellulolytic activities were determined by averaging diameters of clear zones around fungal colonies (Poloni et al. 2009). 
Enhancing the adhesion of $P$. frequentans conidia to sugar beet plants and its relationship with the biocontrol of

\section{C. beticola}

To study the efficiency of $P$. frequentans against $C$. beticola, field experiments were carried out at the Nubaria Research Station, El-Behera, Governorate, Egypt, during the sugar beet growing seasons 2014/15 and 2015/16. Seeds of Pleno sugar beet cultivar (multigerm seeds) obtained from Nubaria Sugar Refining Company (NSRC) were sown directly in plots of $3 \times 3.5 \mathrm{~m}^{2}$ arranged in a completely randomized design, with three plots for each treatment as replicates. Sixty days old plants were sprayed by $C$. beticola spore suspension at the concentration of $1 \times 10^{5}$ spores/ml as mentioned by El-Fawy (2016).

For obtaining conidial suspension, $P$. frequentans (isolate No. 4) was grown on PDA plates for 7 days at $25{ }^{\circ} \mathrm{C}$ in the dark (Guijarro et al. 2017). The concentration of spore suspension was adjusted to $1 \times 10^{5}$ per milliliter of water, using a hemacytometer. Agar, starch flour, white glue, gum, and a commercial adhesive (Triton Mok: $5 \% \mathrm{~K}_{2} \mathrm{O} w / v$ obtained from Moka Group Company, Egypt) were added at $1 \%$ to conidia spore suspensions of $P$. frequentans before inoculation. The sugar beet plants were treated with a spore suspension of $P$. frequentans pre- and post-infection with C. beticola. Each treatment received two sprays (10 days between each one). The fungicide Score 25\% (Difenoconazole 25\%) obtained from Syngenta Company, Switzerland, was applied at concentration of $0.50 \mathrm{~cm}^{3} / 1$ water as a control El-Fawy and Abo-Elyousr (2016).

Disease severity was calculated a week after the second spray, using the diseased scales by Jones and Windels (1991) as follows: $0=$ no leaf lesions, $1=25 \%$ or less-infected leaf area, $2=26$ to $50 \%, 3=51$ to $75 \%$ and
$4=76$ to $100 \%$ infected leaf area. At the end of the experiment, root yield and sugar percent were determined. Sugar percent was measured at the sugar factory laboratory at Nobaryia Sugar Refining Company, using standard polarimetric method estimated by Schneider et al. (2002).

\section{Statistical analysis}

The obtained data were subjected to statistical analysis using the MSTAT-C (1991) program version 2.10. Least significant difference (LSD) was employed to test for significant difference between treatments at $P=0.05$ (Gomez and Gomez 1984).

\section{Results and discussion}

Isolation and identification of fungal isolates

The fungal isolates were identified as $P$. frequentans according to their morphological and microscopic characteristics of conidia spores (Pitt 1979) and confirmed by Assiut University Mycological Center (AUMC). The pathogenicity of $P$. frequentans isolates was tested on different species of plants, i.e., sugar beet, table beet, turnip, spinach, Swiss chard, and radish under greenhouse conditions to determine the pathogenic capability of the fungal isolates. All $P$. frequentans isolates were nonpathogenic to the tested plant species (unpublished data).

\section{Antagonistic effect of $P$. frequentans isolates on $C$. beticola in vitro}

The tested isolates of $P$. frequentans were able to inhibit the mycelial growth of $C$. beticola but the isolates varied in their ability to antagonistic effect (Figs. 1 and 2). In general, $P$. frequentans isolate No. 4 exhibited the highest antagonistic effect toward the tested isolate of the pathogen, followed by isolate No. 2. The high ability of

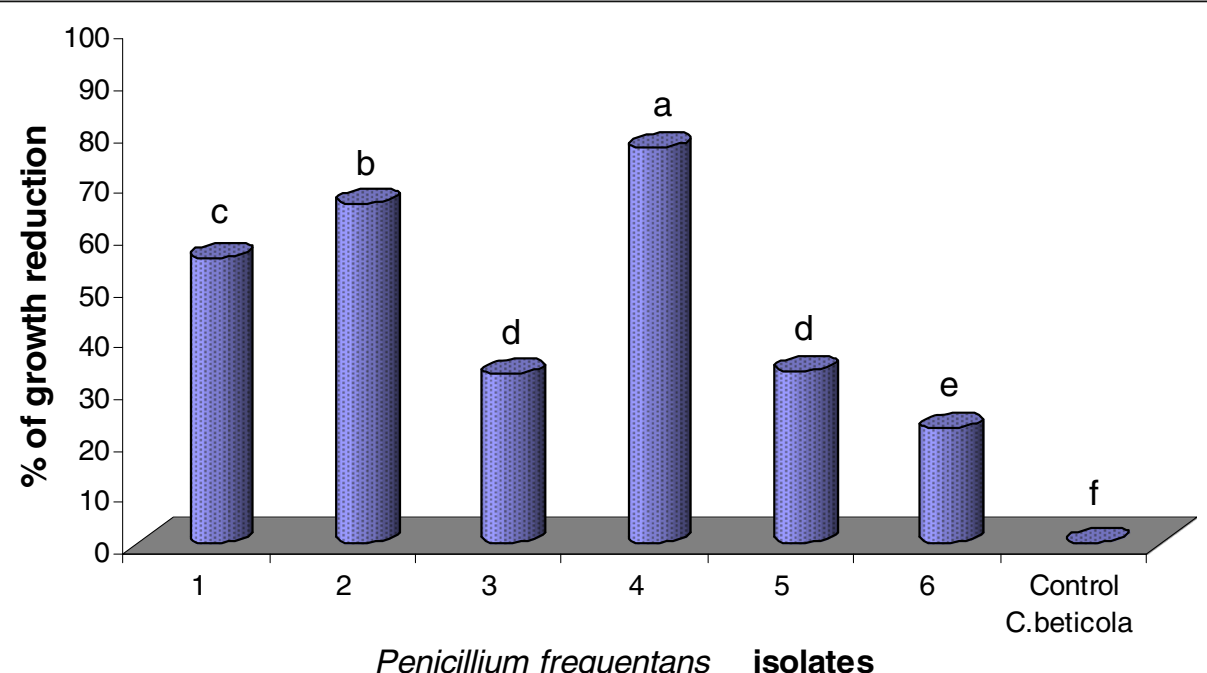

Fig. 1 Antagonistic effect of Penicillium frequentans isolates on the growth of Cercospora beticola in vitro. Different letters indicate significant differences among isolates according to Duncan's multiple range test $(P<0.05)$ 


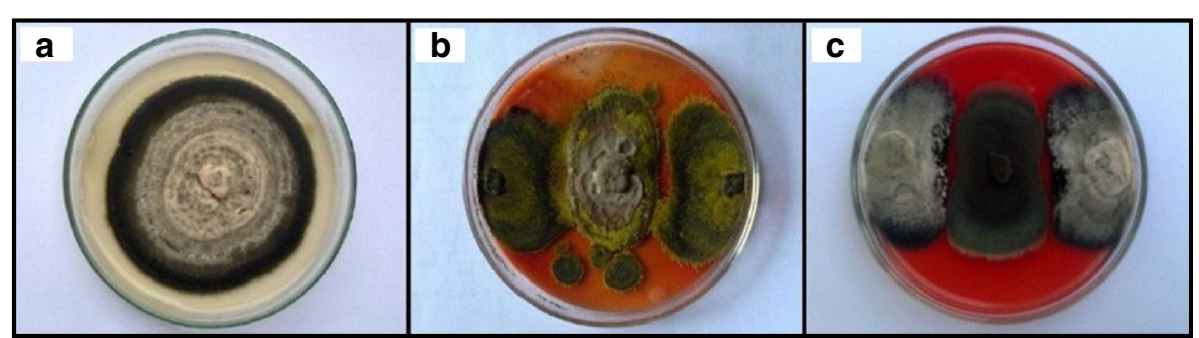

Fig. 2 Inhibition of mycelial growth of Cercospora beticola by Penicillium frequentans. a Control with C. beticola. b P. frequentans has grown rapidly over the mycelium of $C$. beticola. $\mathbf{c}$ Inhibition zone between $P$. frequentans and $C$. beticola

these isolates to inhibit the pathogen is due to the production of some toxic substances and hydrolytic enzymes such as pectinase and cellulase, which could degrade the cell wall of the pathogen. Obtained results agree with those reported by several authors, (Rancic et al. 2006), who found that Penicillium species produce a much diversified range of active secondary metabolites, including antibacterial (Lucas et al. 2007) and antifungal substances (Nicoletti et al. 2007) and also potent mycotoxins (Frisvad and Samson 2004).

\section{Effect of culture filtrates of $P$. frequentans on mycelial growth of $C$. beticola in vitro}

The results of this experiment in Table 1 indicate that addition of culture filtrate of $P$. frequentans to the medium significantly reduced the mycelial growth of the pathogen. Culture filtrate of $P$. frequentans reduced $(P=0.05)$ the mycelial growth of the target fungal pathogen at the tested concentrations of culture filtrate. The highest growth inhibition was reported at $40 \%$ culture filtrate concentration $(v / v)$. These results are in agreement with those obtained by M-Sagasta (1986) who found that the isolate of $P$. frequentans, from olive fruits, was shown to produce frequent and highly antagonistic to Geotrichum candidum.

Table 1 Effect of different concentrations of culture filtrate of Penicillium frequentans isolates on mycelial growth of Cercospora beticola in vitro

\begin{tabular}{llll}
\hline $\begin{array}{llll}\text { Culture filtrate } \\
\text { concentration \% }\end{array}$ & \multicolumn{3}{l}{ Mycelial growth inhibition \% } \\
\cline { 2 - 3 } & \multicolumn{2}{l}{ Penicillium frequentans } & Mean \\
\cline { 2 - 3 } & Iso. No. 2 & Iso. No. 4 & \\
\hline 0 & $0.00 \mathrm{~g}$ & $0.00 \mathrm{~g}$ & $0.00 \mathrm{f}$ \\
5 & $23.70 \mathrm{f}$ & $22.22 \mathrm{f}$ & $22.96 \mathrm{e}$ \\
10 & $31.48 \mathrm{e}$ & $30.74 \mathrm{e}$ & $31.11 \mathrm{~d}$ \\
20 & $37.04 \mathrm{C}$ & $34.81 \mathrm{~d}$ & $35.93 \mathrm{C}$ \\
30 & $57.41 \mathrm{~b}$ & $55.93 \mathrm{~b}$ & $56.67 \mathrm{~b}$ \\
40 & $67.41 \mathrm{a}$ & $68.52 \mathrm{a}$ & $67.97 \mathrm{a}$ \\
\hline
\end{tabular}

Values in the column followed by different letters indicate significant differences among treatments according to LSD at 0.05
In the present study, culture filtrate of isolate No. 2 was more effective on the pathogen than the culture filtrate of isolate No. 4. Data also indicated that mycelial growth of $C$. beticola significantly decreased as the concentration of culture filtrate increased and reached its maximum reduction at concentration of $40 \%$ (Fig. 3). There is a highly significant difference between the all tested concentrations $(P=0.05)$. Ali et al. (2011) found that culture filtrates of $P$. citrinum, $P$. digitatum, $P$. expansum, $P$. verrucosum, and $P$. viridicatum were the most effective to control Salmonella gallinarum. Three of Penicillium species isolated from Picea glehnii seeds produced antifungal compounds: patulin, citrinin, palitantin, and frequentin (Yamaji et al. 2001). Pythium vexans was more sensitive to these antifungal compounds. Also, Abdel-Rahim and Abo-Elyousr (2018) found that endophytic Talaromyces pinophilus had high activities of cell wall-degrading enzymes and it may be a promising biocontrol agent of phytopathogenic fungi.

\section{Pectinase and cellulase activity}

All $P$. frequentans isolates were able to produce pectinase and cellulase at different degrees. Data in Fig. 4 indicate that isolate No. 4 has the best producing

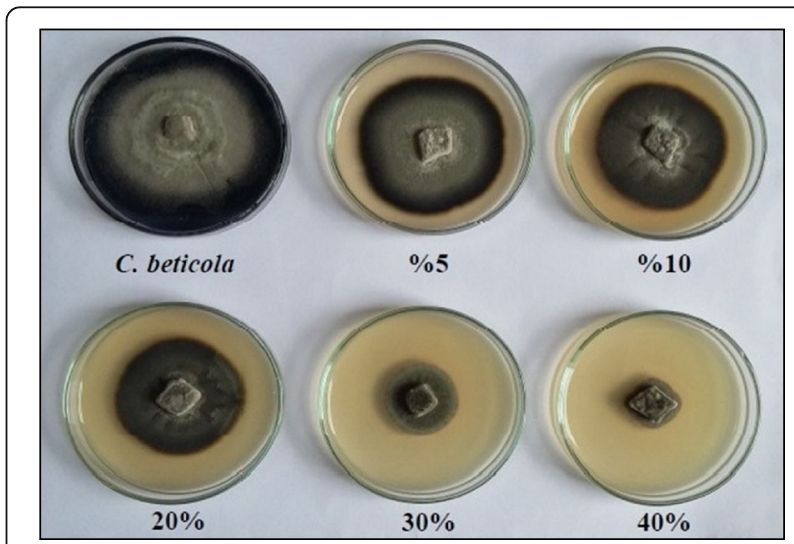

Fig. 3 Effect of culture filtrate of Penicillium frequentans isolate No. 4 on mycelial growth of Cercospora beticola in vitro 


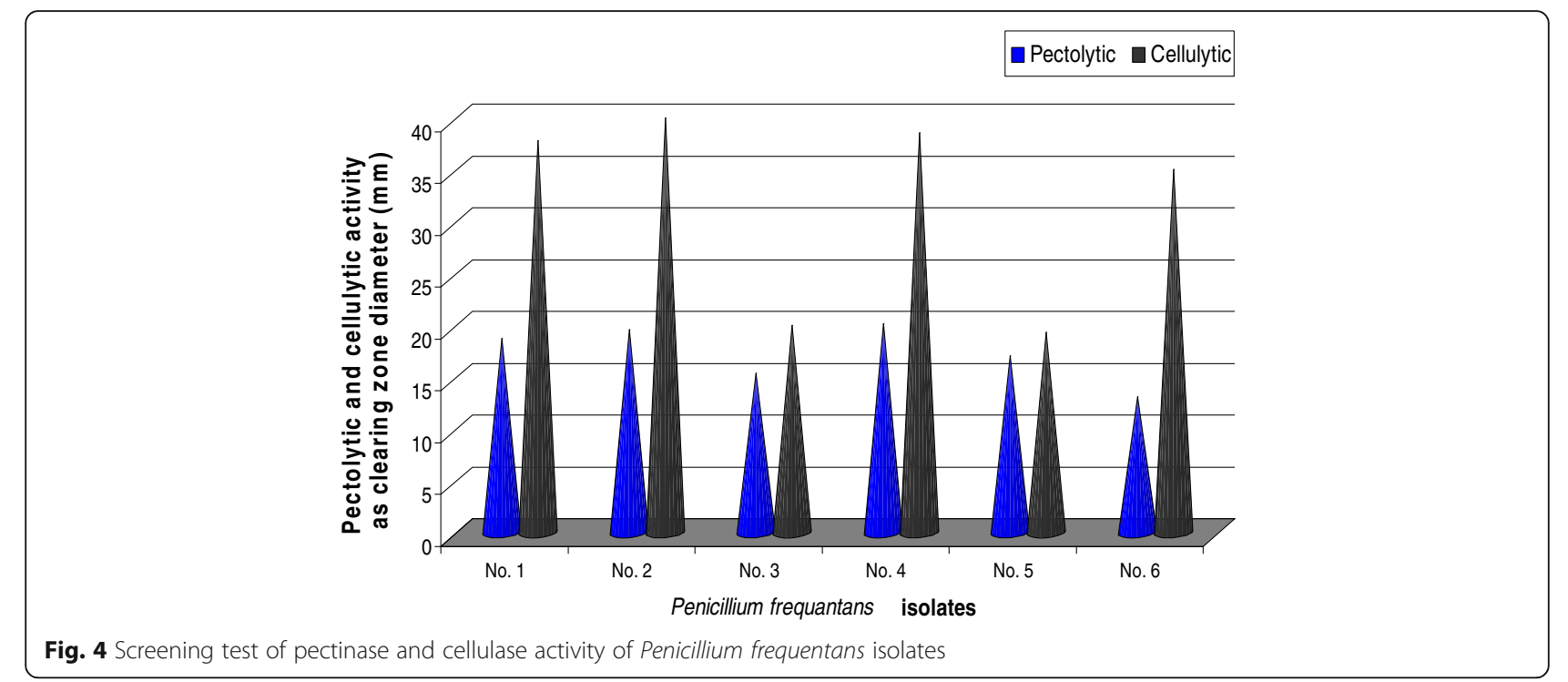

pectinase $(20.20 \mathrm{~mm})$, followed by No. $2(19.60 \mathrm{~mm})$. However, isolate No. 6 had the lowest producing pectinase $(13.10 \mathrm{~mm})$. Data also indicated that cellulase activity of all isolates ranged from 19.30 to $40.00 \mathrm{~mm}$. Isolate No. 2 had the best producing cellulase $(40 \mathrm{~mm})$, while isolate No. 6 had the lowest $(19.30 \mathrm{~mm})$. These results are in agreement with those obtained by Kawano et al. (1999) who noted that $P$. frequentans produced high levels of extracellular pectinases after $24 \mathrm{~h}$ of incubation in submerged culture. Moreover, many researches have shown the ability of different Penicillium species to produce some enzymes, such as P. italicum (Alana et al. 1990), pectolytic molds (Fawole and Odunfa 1992), P. viridicatum RFC3 (Silva et al. 2002), $P$. roqueforti (Pericin et al. 2007), and $P$. expansum (Cardoso et al. 2007). From these results, it is clear that there was a correlation between enzyme activity and the antagonistic ability for each isolate. The isolates with high antagonistic ability were the most enzyme activity. A cellulase enzyme had the ability to degrade the fungal cell wall which is an important mechanism of fungal inhibition (Reetha et al. 2014).

\section{Effect of foliar spraying with spore suspension of $P$. frequentans on reducing Cercospora leaf spot disease of sugar beet under field conditions}

The application of the tested adhesive (agar, starch flour, white glue, gum, and Triton Mok) to the spore suspension of $P$. frequentans was very effective in reducing the disease severity of Cercospora leaf spot of sugar beet. Data in Table 2 indicate that amendment of the spore suspension with adhesives was very beneficial for increasing effectiveness of the suspension of $P$. frequentans for controlling the disease than the spore suspension alone. Moreover, treatment with adhesives pre-infection was more effective than that post-infection. Adding starch flour at $1 \%$ pre-infection caused the highest reduction of

Table 2 Effect of foliar treatment with spore suspension of Penicillium frequentans on Cercospora leaf spot of sugar beet under field conditions during 2014/15 and 2015/16 growing seasons

\begin{tabular}{|c|c|c|c|c|c|c|}
\hline \multirow[t]{3}{*}{ Adhesives } & \multicolumn{6}{|c|}{ Disease severity (\%) } \\
\hline & \multicolumn{3}{|l|}{ Season 2014/15 } & \multicolumn{3}{|l|}{ Season 2015/16 } \\
\hline & Before infection & After infection & Mean & Before infection & After infection & Mean \\
\hline Agar & 11.25 ef & 12.50 fce & $11.88 \mathrm{~cd}$ & $12.08 \mathrm{e}$ & $17.19 \mathrm{C}$ & $15.43 d$ \\
\hline Starch flour & 10.42 ef & 10.52 ef & 10.47 de & $10.31 \mathrm{f}$ & $10.33 f$ & $10.57 \mathrm{f}$ \\
\hline White glue & 10.94 ef & $11.98 \mathrm{e}$ & $11.46 \mathrm{~d}$ & 11.15 ef & $15.63 \mathrm{c}$ & $13.39 \mathrm{e}$ \\
\hline Gum & 13.02 ce & $14.17 \mathrm{C}$ & $13.60 \mathrm{c}$ & $15.10 \mathrm{c}$ & $16.25 d$ & $15.68 d$ \\
\hline Triton Mok & $15.21 \mathrm{c}$ & $15.52 \mathrm{c}$ & $15.37 \mathrm{C}$ & $15.73 c$ & 18.75 bc & $16.46 \mathrm{bc}$ \\
\hline Without adhesives & $16.67 \mathrm{~b}$ & $18.75 \mathrm{~b}$ & $17.71 \mathrm{~b}$ & $17.50 \mathrm{c}$ & $19.19 \mathrm{~b}$ & $18.34 \mathrm{~b}$ \\
\hline Score $25 \%$ & $7.81 \mathrm{~g}$ & $8.44 \mathrm{~g}$ & $8.13 f$ & $8.33 \mathrm{f}$ & $9.17 \mathrm{f}$ & $8.75 \mathrm{~g}$ \\
\hline Control (untreated) & $43.23 \mathrm{a}$ & $43.23 \mathrm{a}$ & $43.23 \mathrm{a}$ & $42.19 \mathrm{a}$ & $42.19 \mathrm{a}$ & $42.19 \mathrm{a}$ \\
\hline
\end{tabular}

Values in the column followed by different letters indicate significant differences among treatments according to LSD at 0.05 
disease severity (10.42 and 10.31\%) at both seasons, followed by white glue (10.94 and 11.15\%). On the other hand, the fungicide Score 25\% gave the highest reduction of disease severity at concentration $0.50 \mathrm{~cm}^{3} / 1$ water $(7.81$ and $8.33 \%$ ) at both seasons $2014 / 15$ and 2015/16, respectively, when used pre-infection. Triton Mok as a commercial adhesive gave the lowest reduction of disease severity (15.21 and 15.73\%). The results showed that there were significant differences among the adhesives $(P=0.05)$ in increasing the effectiveness of the spore suspension in controlling the disease. Such results are in line with those reported by Larena et al. (2010) who found that incorporation of 2.5\% methylcellulose into an Epicoccum nigrum conidial formulation; the adhesion of $E$. nigrum conidia to peach surfaces improves and results in effective biocontrol of brown rot. McGuire and Shasha (1995) found that the use of the pregelatinized flour formulation promoted $B$. thuringiensis adhesion even after multiple rain events. $P$. frequentans produced antifungal frequentin and palitantin and inhibited spore germination and germ-tube growth of M. laxa (De Cal et al. 1988). P. frequentans increased the average percentage of surviving seedlings when inoculated together with Pythium vexans, but the increase was not significant (Yamaji et al. 2004). The peach trees inoculated with $P$. frequentans inhibited the infection by a pathogenic fungus, M. laxa (Melgarejo et al. 1986). P. frequentans produced antifungal frequentin and palitantin and inhibited spore germination and germ-tube growth of M. laxa (De Cal et al. 1988).

\section{Effect of foliar spraying with spore suspension of $P$. frequentans on root yield and sugar percent of sugar beet}

Data presented in Table 3 show that treatment with $P$. frequentans spore suspension significantly $(P=0.05)$ improved agronomic characters of the sugar beet crop, i.e., root yield and sugar content at both seasons (2014/15 and 2015/16). Data also indicated that spraying the spore suspension showed a significant positive effect on the root yield and sugar percent. From the previous results, it is a clear that root yield and sugar percent were reduced by increasing disease severity. Data also showed that the highest root yield was recorded in plots treated with a spore suspension amended with white glue at concentration $1 \%$ being 36.90 and 34.04 ton/feddan at seasons 2014/15 and $2015 / 16$, respectively, compared with the other adhesives $(P=0.05)$. The increase in root yield was due to the increased effectiveness of the spore suspension in the control of the disease. The sugar percent was highest with Score 25\% treatment (21.84 and 21.97\%), followed by white glue (21.82 and $21.74 \%)$ at the two seasons, respectively, $(P=0.05)$ than the control treatments (17.41 and $16.03 \%)$. These results are in agreement with those reported by Ziedan and Farrag (2011) who found that application of yeasts as biocontrol agents for controlling foliar diseases on sugar beet was effective in increasing root yield and sugar percent. However, adding Triton Mok to the spore suspension at $1 \%$ gave the lowest values of root yield and sugar percent at both seasons.

\section{Conclusions}

From the results, it could be concluded that the application of the adhesives to spore suspension before application led to improve target coverage, adhesion of conidia to sugar beet plants, and increased effectiveness in controlling the disease. The use of $P$. frequentans in the biological control of foliar diseases should be given more attention.

Table 3 Effect of foliar treatment with spore suspension of Penicillium frequentans on root yield and sugar percent of sugar beet under field conditions during 2014/15 and 2015/16 growing seasons

\begin{tabular}{|c|c|c|c|c|c|c|c|c|}
\hline \multirow[t]{3}{*}{ Adhesives } & \multicolumn{4}{|c|}{ Root yield (tons/feddan) } & \multicolumn{4}{|l|}{ Sugar \% } \\
\hline & \multicolumn{2}{|c|}{$\begin{array}{l}\text { Before infection } \\
\text { Seasons }\end{array}$} & \multicolumn{2}{|c|}{$\begin{array}{l}\text { After infection } \\
\text { Seasons }\end{array}$} & \multicolumn{2}{|c|}{$\begin{array}{l}\text { Before infection } \\
\text { Seasons }\end{array}$} & \multicolumn{2}{|c|}{$\begin{array}{l}\text { After infection } \\
\text { Seasons }\end{array}$} \\
\hline & $2014 / 15$ & $2015 / 16$ & $2014 / 15$ & $2015 / 16$ & $2014 / 15$ & $2015 / 16$ & $2014 / 15$ & 2015/ 16 \\
\hline Agar & $33.75 \mathrm{bc}$ & $33.09 \mathrm{bc}$ & 29.20 ef & 26.40 ef & $19.06 \mathrm{bc}$ & $21.46 a$ & $19.60 \mathrm{bc}$ & $19.54 \mathrm{bc}$ \\
\hline Starch flour & $34.60 \mathrm{~b}$ & $33.02 \mathrm{bc}$ & $32.72 \mathrm{~cd}$ & 29.81 ef & $21.82 \mathrm{a}$ & $21.11 b$ & $21.74 \mathrm{a}$ & $20.20 b$ \\
\hline White glue & $36.90 \mathrm{ab}$ & $34.04 b$ & $35.41 \mathrm{ab}$ & $33.60 \mathrm{bc}$ & $21.02 b$ & $21.51 \mathrm{a}$ & $20.14 b$ & $21.63 \mathrm{a}$ \\
\hline Gum & $34.87 \mathrm{~b}$ & $34.13 b$ & 29.12 de & $26.71 \mathrm{ef}$ & 19.78 bc & $19.80 \mathrm{bc}$ & $19.56 \mathrm{bc}$ & $18.08 \mathrm{de}$ \\
\hline Triton Mok & $33.67 \mathrm{bc}$ & 29.78 de & 26.30 ef & 25.03 ef & $17.56 f$ & $18.74 d$ & $18.79 \mathrm{~d}$ & $18.34 \mathrm{de}$ \\
\hline Without adhesives & $24.90 \mathrm{fg}$ & $30.34 d$ & $30.64 d$ & $28.11 \mathrm{de}$ & $17.41 \mathrm{f}$ & $18.11 \mathrm{de}$ & 18.45 de & $16.25 \mathrm{~g}$ \\
\hline Score $25 \%$ & $38.85 \mathrm{a}$ & $37.90 \mathrm{da}$ & $37.39 \mathrm{a}$ & $36.44 \mathrm{a}$ & $21.82 \mathrm{a}$ & $21.97 \mathrm{a}$ & $21.74 \mathrm{a}$ & $20.34 b$ \\
\hline Control (untreated) & $20.45 b$ & $22.02 \mathrm{~h}$ & $20.45 \mathrm{~h}$ & $22.02 \mathrm{~h}$ & $17.41 \mathrm{f}$ & $16.03 \mathrm{~g}$ & $17.41 \mathrm{f}$ & $16.03 \mathrm{~g}$ \\
\hline
\end{tabular}

Values in the column followed by different letters indicate significant differences among treatments according to LSD at 0.05 


\section{Abbreviation}

ME: Malt extract

\section{Authors' contributions}

All authors contributed equally in the manuscript. All authors read and approved the final manuscript.

\section{Ethics approval and consent to participate}

Not applicable.

\section{Competing interests}

The authors declare that they have no competing interests.

\section{Publisher's Note}

Springer Nature remains neutral with regard to jurisdictional claims in published maps and institutional affiliations.

\section{Author details}

${ }^{1}$ Agricultural Botany Department, Plant Pathology Branch, Faculty of Agriculture, Al-Azhar University (Assiut Branch), Assiut, Egypt. ${ }^{2}$ Plant Pathology Department, Faculty of Agriculture, Assiut University, Assiut 71526, Egypt.

Received: 12 February 2018 Accepted: 24 May 2018

\section{Published online: 06 June 2018}

\section{References}

Abdel-Rahim IR, Abo-Elyousr KAM (2018) Talaromyces pinophilus strain AUN-1 as a novel mycoparasite of Botrytis cinerea, the pathogen of onion scape and umbel blights. Microbiol Res 212-213C:1-9

Abo-Elyousr KAM, Sobhy I. I. Abdel-Hafez, Abdel-Rahim IR (2014) Isolation of Trichoderma and evaluation their antagonistic potentiality against Alternaria porri. J Phytopatholo 162:567-574.

Alana A, Alkorta I, Dominguez JB, Llama MJ, Serra JL (1990) Pectin lyase activity in a Penicillium Italicum strain. Appl Environ Microbiol 56:3755-3759

Ali A, Haider MS, Khokhar I, Bashir U, Mushtaq S, Mukhtar I (2011) Antibacterial activity of culture extracts of Penicillium species against soil-borne bacteria. Mycopathologia 9(1):17-20

Bonaterra A, Cabrefiga J, Camps J, Montesinos E (2007) Increasing survival and efficacy of a bacterial biocontrol agent of fire blight of rosaceous plants by means of osmoadaptation. Microbiol Ecol 61(1):185-195

Cardoso PG, Queiroz MV, Pereira OL, Araujo EF (2007) Morphological and molecular differentiation of the pectinase producing fungi Penicillium expansum and Penicillium griseoroseum. Braz J Microbiol 38:71-77

Carlton WW, Stack ME, Eppley RM (1976) Hepatic alterations produced in mice by xanthomegnin and viomellein, metabolites of Penicillium viridicatum. Toxicol Appl Pharmacol 38:455-459

De Cal A, Sagasta EM, Melgarejo P (1988) Antifungal substances produced by Penicillium frequentans and their relationship to the biocontrol of Monilinia laxa. Phytopathology 78:888-893

De Cal A, Sagasta EM, Melgarejo P (1990) Biological control of peach twigs blight (Monilinia laxa) with Penicillium frequentans. Plant Pathol J 39:612-618

El-Fawy MM (2016) Influence spraying of two borate compounds on controlling Cercospora leaf spot disease and productivity of sugar beet. Egyptian J Phytopathol 44(1):113-126

El-Fawy MM, Abo-Elyousr KAM (2016) Effect of certain chemical compounds on controlling common bean rust disease. Arch Phytopathol Plant Protect 49: 19-20 522-532

Fawole OB, Odunfa SA (1992) Pectolytic molds in Nigeria. Lett Appl Microbio Biotechnol 15:266-268

Frisvad JC, Samson RA (2004) Polyphasic taxonomy of Penicillium subgenus Penicillium: a guide to identification of food and air-borne terverticillate Penicillia and their mycotoxins. Stud Mycol 49:1-174

Gomez KA, Gomez AA (1984) Statistical procedures for agriculture research, 2nd edn. Willey, New York, p 680

Guijarro B, Hernandez-Escribano L, Larena I, Melgarejo P, De Cal A (2017) Competition is the mechanism of biocontrol of brown rot in stone fruit by Penicillium frequentans. BioControl 62:557-566

Guijarro B, Larena I, Melgarejo P, De Cal A (2006) Effect of drying on conidial viability of Penicillium frequentans, a biological control agent against peach brown rot disease caused by Monilinia spp. Biocontrol Sci Technol 16:257-269
Guijarro B, Melgarejo P, De Cal A (2007) Effect of stabilizers on the shelf-life of Penicillium frequentans conidia and their efficacy as a biological agent against peach brown rot. Int J Food Microbiol 113:117-124

Jones, R. K. and C. E. Windels. 1991. A management model for Cercospora leaf spot of sugar beets. Minnesota Extension Service, AGFO- 5643-E

Kawano CY, Chellegatti MASC, Said S, Fonseca MJV (1999) Comparative study of intracellular and extracellular pectinases produced by Penicillium frequentans. Biotechnol Appl Biochem 29:133-140

Larena I, De Cal A, Melgarejo P (2010) Enhancing the adhesion of Epicoccum nigrum conidia to peach surfaces and its relationship to the biocontrol of brown rot caused by Monilinia laxa. J Appl Microbiol 109:583-593

Lucas EMF, Castro MCM, Takahashi JA (2007) Antimicrobial properties of sclerotiorin, isochromophilone $\mathrm{VI}$ and pencolide, metabolites from a Brazilian cerrado isolate of Penicillium sclerotiorum van Beyma. Braz J Microbiol 38:785-789

McGuire MR, Shasha BS (1995) Starch encapsulation of microbial pesticides. In: Hall FR, Barry JW (eds) Biorational pest control agents: formulation and delivery. American Chemical Society, Washington, DC, pp 229-237

Melgarejo P, Carrillo R, M-Sagasta E (1986) Potential for biological control of Monilinia laxa in peach twigs. Crop Prot 5:422-426

Mohamed AA, Saeed FA, Hassan MHA, El-Fawy MM (2008) Efficacy of biological control in reducing the incidence of wilt and damping-off diseases in cumin. Egypt J Appl Sci 23(11):46-57

M-Sagasta I (1986) Antagonismo de Penicillium frequentans Westling sobre Penicillium crustrosum Thomy Geotrichum candidum Link ex Leman, aislados de aceitunas almacenadas en troje. Tesina de Licenciatura en Ciencias Quimicas. Universidad Complutense de Madrid, Madrid, p 140

MSTAT-C (1991) A software program for the design, management and analysis of agronomic research experiments. Michigan State University, East Lansing

Nicoletti R, Lopez-Gresa MP, Manzo E, Carella A, Ciavatta ML (2007) Production and fungitoxic activity of Sch 642305, a secondary metabolite of Penicillium canescens. Mycopathologia 163:295-301

Panda SS, Sahoo K, Das R, Dhal NK (2012) Pectinolytic and cellulolytic activity of soil fungal isolates from similipal bioreserve forest. World Environ 2(2):1-3

Pericin DM, Madarev SZ, Radulovic LM, Skrinjar M (2007) Production of exo-pectinase by Penicillium roqueforti using pumpkin oil cake. Nat Sci J 113:313-320

Piszczek J, Pieczul K, Kiniec A (2017) First report of G143A strobilurin resistance in Cercospora beticola in sugar beet (Beta vulgaris) in Poland. J Plant Dis Protect $125 ; 99-101$

Pitt, J. I. 1979. The genus Penicillium and its teleomorphic states Eupenicillium and Talaromyces Academic Press Inc, London

Poloni A, Pessi IS, Frazzon APG, Van Der Sand ST (2009) Morphology, physiology and virulence of Bipolaris sorokiniana isolates. Curr Microbiol 59:267-273

Rancic A, Sokovic M, Karioti A, Vukojevic J, Skaltsa H (2006) Isolation and structural elucidation of two secondary metabolites from the filamentous fungus Penicillium ochrochloron with antimicrobial activity. Environ Toxicol Phar J 22:80-84

Reetha S, Bhuvaneswari G, Thamizhiniyan P, Ravi Mycin T (2014) Isolation of indole acetic acid (IAA) producing rhizobacteria of Pseudomonas fluorescens and Bacillus subtilis and enhance growth of onion (Allim cepa. L.). Int J Curr Microbiol Appl Sci 3(2):568-574

Ropars J, Aguileta G, de Vienne DM, Giraud T (2014) Massive gene swamping among cheese-making Penicillium fungi. Microb Cell 1:107-109

Schisler DA, Slininger PJ, Behle RW, Jackson MA (2004) Formulation of Bacillus spp. for biological control of plant diseases. Phytopathology 94:1267-1271

Schneider K, Schafer-Pregl R, Borchardt D, Salamini F (2002) Mapping QTLs for sucrose content, yield and quality in a sugar beet population fingerprinted by EST-related markers. Theor Appl Genet 104:1107-1113

Shane WW, Teng PS (1992) Impact of Cercospora leaf spot on root weight, sugar yield and purity of Beta vulgaris. Plant Dis 76:812-820

Silva D, Martins ES, Silva R, Gomes E (2002) Pectinase production from Penicillium viridicatum RFC3 by solid state fermentation using agricultural residues and agro-industrial by-product. Braz J Microbiol 33:318-324

Silva MG, Furtado NAJC, Pupo MT, Fonseca MJV, Said S, Filho AAS, Bastos JK (2004) Antibacterial activity from Penicillium corylophilum. Microbiol Res 159(4):317-322

Yamaji K, Fukushi Y, Hashidoko Y, Tahara S (2004) Penicillium frequentans isolated from Picea glehnii seedling roots as a possible biological control agent against damping-off. Ecol Res 20:103-107

Yamaji K, Fukushi Y, Hashidoko Y, Yoshida T, Tahara S (2001) Penicillium fungi from Picea glehnii seeds protect the seedlings from damping-off. New Phytol 152:521-531

Ziedan EHE, Farrag ESH (2011) Application of yeasts as biocontrol agents for controlling foliar diseases on sugar beet. Plants J Agric Technol 7(6):1789-1799 